\title{
The nurse as a member of an interprofessional team in the care of the oral cavity of cancer patients
}

\section{Pielęgniarka jako członek zespołu interdyscyplinarnego opiekującego się chorymi na raka jamy ustnej}

\author{
Katarína Zrubáková1, Maria Lehotska1, Anna Herinková2, Roman Podoba² \\ 1Department of Nursing, Faculty of Health, Catholic University, Ruzomberok, Slovak Republic \\ 2Department of Radiation and Clinical Oncology, Central Military Hospital - University Hospital, Ruzomberok, Slovak Republic
}

Medical Studies/Studia Medyczne 2020; 36 (3): 230-234

DOI: https://doi.org/10.5114/ms.2020.99551

\section{Introduction}

Anti-tumour treatment includes surgical, radiation, medication (chemotherapy, hormonal and biological treatment), supportive, and in some cases also palliative treatment. Chemotherapy and radiotherapy, or a combination of the two, involve the most clinical manifestations of adverse effects [1, 2]. Adverse effects may be local or systematic and often they subside in the course of several weeks and months after the end of treatment $[3,4]$. In the case of patients with unfavourable prognosis, the adverse effects continue for the rest of their life. One of the most frequently occurring complications is damage of oral mucosa $[5,6]$. The oral cavity is not only endangered by radiotherapy (particularly with radiation in the area of head and neck) and chemotherapy, but it also suffers the consequences of neutropaenia and overall weakening of the body. The role of professionals is to use timely supportive and targeted treatment to reduce the damage and to attenuate the accompanying symptoms such as pain, dry mouth, xerostomia, oral infection, lack of appetite, swallowing disorders, and others.

Nursing care and the individual interventions of the nurse depend on the medical condition of the patient, and the intensity and type of oncological treatment. An essential element is assessment of the patient. Nursing interventions are aimed at prevention and treatment of mucositis, xerostomia, lack of appetite, malnutrition, pain, difficulties with swallowing, and weakened immune system. An essential element of the care is the patient's education (regarding adverse effects of the treatment, hygienic care, treatment, and alleviation of symptoms) [1].

The case study was carried out at the Department of Radiation and Clinical Oncology (DRCO) of the Central Military Hospital - University Hospital $(\mathrm{CMH} \mathrm{UH})$. The study was preceded by an analysis of medical records focused on the occurrence of adverse reactions after chemotherapy and radiotherapy treatment and on the most frequent nursing interventions. Based on the assessed records, we determined that the most frequent adverse effects after chemotherapy treatment were nausea, vomiting, hair loss, fatigue, changes in oral cavity, increased temperature, and neutropaenia. In the case of radiotherapy, it was change of skin at the place of radiation, changes in oral cavity, and fatigue. Oral care consisted of general and local treatment, changes in diet, and sufficient intake of liquids.

The main objective was to present specifics of nursing and collective oral care for patients undergoing oncostatic treatment.

Partial objectives:

1. To point out the importance of interdisciplinary care in the treatment of oncology patients.

2 . To compare oral care for chemotherapy and radiotherapy patients.

The main method was a case study. Additional methods were unstructured and semi-structured interview, observation, document analysis, assessment scales (VAS, severity assessment criteria for oral mucositis according to the WHO, assessment scale for oral cavity complications and oral mucositis according to the NCI CTC).

The study subjects were patients undergoing treatment at the DRCO of CMH UH. The first patient received chemotherapy treatment, and the second patient received radiotherapy treatment in combination with chemotherapy. The choice of patients was intentional. Data were collected on the basis of informed consent of both patients.

Case study 1: 49-year-old patient with hypopharyngolaryngeal carcinoma (ca) lateris dextri, suspected metastasis in cervical lymph nodes (LN) on the right, T3-4aN1Mx, and stage IV.A. Vertebrogenic algic syndrome (of lumbosacral region of the spine). State after (st.p.) introduction of Percutaneous endoscopic gastrostomy (PEG) 02/2018 and tracheostomy 02/2018 (Table 1).

Surgeries: st.p. directoscopy. Histologisation (LN) on the right, group II-III. 
Table 1. WHO Oral Mucositis Scale - case study 1

\begin{tabular}{|c|c|c|c|c|c|}
\hline \multirow[t]{2}{*}{ Day } & \multicolumn{5}{|c|}{ Degree of difficulty } \\
\hline & $\begin{array}{c}0 \\
\text { None }\end{array}$ & $\begin{array}{c}1 \\
\text { Soreness, } \\
\text { erythema, no } \\
\text { ulceration }\end{array}$ & $\begin{array}{c}2 \\
\text { Erythema } \\
\text { ulceration, } \\
\text { patient can } \\
\text { swallow solid } \\
\text { diet }\end{array}$ & $\begin{array}{c}3 \\
\text { Erythema } \\
\text { ulceration, } \\
\text { patient cannot } \\
\text { swallow solid } \\
\text { diet }\end{array}$ & $\begin{array}{l}4 \\
\text { Mucositis to } \\
\text { the extent that } \\
\text { alimentation is } \\
\text { not possible }\end{array}$ \\
\hline 1 & No trouble & - & - & - & - \\
\hline 6 & - & - & Yes & - & - \\
\hline 7 & - & - & - & Yes & - \\
\hline 8 & - & - & - & - & Yes \\
\hline 9,10 & - & - & Yes & - & - \\
\hline $\begin{array}{l}\text { Last day of } \\
\text { hospitalisation }\end{array}$ & - & Yes & - & - & - \\
\hline
\end{tabular}

Family medical history: mother -66 years old, undergoing bronchial asthma treatment; father - died at the age of 52, of myocardial infarction; siblings - five, the patient was not familiar with their medical history.

Social and occupational history: working as locksmith abroad.

Allergies - negative.

History of drugs: isosource in PEG, transfusions: A1 posit.

Catamnesis: patient with hypopharyngolaryngeal carcinoma on the right, st.p. directoscopy, histology: keratinising squamous cell carcinoma, $29 \mathrm{LN}$ in $2 \mathrm{mts}$, 1 with perinodal spreading. Checked in on 24.4.2018 at DRCO for the application of oncostatic treatment/ induction chemotherapy 5-fluorouracil, Taxotere, platinum (TPF)-3 set within larynx conservation protocol.

The patient subjectively reports the following: body temperature (BT) within standard limits, and scratchy feeling behind tracheostomy during food intake and otherwise. PEG is functional, the patient is able to eat solid food when swallowed with liquids, and recently the patient has lost $5 \mathrm{~kg}$. The patient does not report pain (VAS 0), is breathing without difficulties, without palpitations and chest pain, has good appetite and bowel movement, and urinates without difficulties. Normal blood parameters were seen when the patient checked in.

On the first day of hospitalisation an intravenous (IV) cannula was introduced to the patient, premedication was administered: Dextromethorphan (DXM) $8 \mathrm{mg}$, and application of the prescribed chemotherapy was initiated: Taxotere, platinum, 5 fluorouracil, for a continuous 5-day regime.

On the second to fifth day no complications were reported and the patient received a combined diet orally and in PEG.
On the sixth day the patient felt weak, reported stomachache, bloating subsiding, and diarrheal stools were reported. Objectively, afebrile, cardiopulmonary compensated, abdomen without peritoneal irritation, free, palpable, peristalsis present through auscultation, lower limbs without swelling, oral cavity (OC) - mucositis second degree, moderate pain VAS 6, not preventing oral intake. Modification of diet was indicated. Assessment according to CTCAE was as follows: localised ulcerations, moderate symptoms, diet adjustment was required.

On the seventh day BT was $38^{\circ} \mathrm{C}$. Blood values were as follows: leukocytes (WBC) $1.1 \times 10^{9} / 1$; Neutrophils $0.30 \times 10^{9} / 1-$ neutropaenia Gr. IV present. High inflammatory activity C-reactive protein (CRP) $185.00 \mathrm{mg} / \mathrm{l}$, procalcitonin $0.190 \mathrm{l}$. Based on doctor's orders, rectal swab taken for cultivation and sensitivity $(C+S)$, nasal swab, throat swab, urine sample for $C$ $+\mathrm{S}$, at $\mathrm{BT}$ above $38^{\circ} \mathrm{C}$ blood sample for blood cultures.

Nursing interventions were focused on monitoring the medical condition of the patient, monitoring OC, measuring physiological functions, and applying general and local treatment. Assessment of mental condition, education, and therapeutic communication.

Initiation of systematic antibiotic treatment (ATB) - Amoksiklav, Flukonazol 200 mg IV, Zarzio. Physiological solution (PS) + Mesocain, 10\% Glucose (G)+ 4 j. Insulin HMR, Reasec, Novalgin IV as necessary in the case of BT increase.

Local treatment of OC - wiping with Borax glycerine, Gelclair three times a day. Physical examination - significant hyperaemia on the tongue. Food administered only through PEG. When speaking, the patient experienced pain, burning and stinging in OC, especially of the tongue.

On the eighth day neutropaenia Gr. was still present. IV Ciprofloxacin $200 \mathrm{mg}$ was added to the medication. 
Application of Zarzio was continued. OC - unchanged condition, recommended flushing and drinking agrimony tea. The mental state of the patient was changing, including feelings of anxiety, depression.

On days 9-10 the patient reported alleviation of the symptoms. Mucositis 2 - pain, redness, continuation of general and local treatment.

At discharge, the patient's physical and psychological symptoms were minimized. Assessment scale for oral mucositis 1, VAS 4 . The patient accepts the current condition and expresses willingness to cooperate in further treatment. The patient was educated on oral care, diet regime, and other treatment options.

Case study 2: 50-year-old patient diagnosed with Ca tonsillae lateris dx. cum MTS ad colli l.dx T1-2N2a $\mathrm{Mx}$ after intra-oral resection of $\mathrm{Ca}$ tonsil on the right with pre-surgical histology, block dissection LN I-V sc. on the right. Nasogastric tube (NG) (20. 7.2018), histologically spinocellular $\mathrm{Ca}$, planned hospitalisation at DRCO for initiation of concomitant post-surgical radiotherapy and chemotherapy treatment (Table 2).

Medical history: Arterial hypertension II. degree, hepatopathy, peptic ulcer disease in medical history, coxarthrosis.

Family medical history: father died at the age of 72 years after bypass surgery; mother died at the age of 60 years; patient does not know the cause; siblings -3 , healthy.

Social and occupational history: working with saw.

Allergies: negative for drugs and foods.

History of drugs: Amlodipin, Flugalin, Akynzeo (before CHT), Gelclair (during RT, CHT), Radiocare, transfusion: A Rh posit.

Abuses: ex-smoker 2 months.

Catamnesis: patient checked in on 11.9.2018 for initiation of concomitant RT, CHT - cis Pt weekly mode, subjectively without cardiovascular and gastro- intestinal symptoms. Afebrile, moderate painfulness in the place of surgery (sg) VAS-2; no other reported.

On the first day of hospitalisation the patient reported moderate pain in the sg. wound and numbness in the right part of the face. Initiated RT for neck area and regionally LN I-V in dosage of $25 \times 2$ Gy using Truebeam. The patient was educated on possible complications related to RT and CHT and means of their elimination: diet adjustment, increased intake of liquids, care of irradiated skin, and oral care.

Nursing interventions were focused on education, regular monitoring of the physical and mental state of the patient, oral cavity checks, application of local and general treatment.

12.9.2018 application of CHT - Cisplatin. After CHT patient reports lack of appetite.

12-18.9.2018 RT applied - the patient reported a feeling of swelling in the neck area, scratchy throat during food intake and otherwise, difficulty swallowing, and he negated any pain. Assessment scale for oral mucositis - 2 later 3 . Adjusted diet - pasty + sipping (Nutridrinks). The patient applied Radiocare on the neck area.

19.9.2018 cisPT was applied - the patient reported lack of appetite, locally in RT area hyperaemic reaction first degree, Radiocare was continued, OC flushing with Gelclair, agrimony tea, Panthenol Tbl- lozenges were added to the treatment. Four-kilogram weight loss was revelaed in weight check-up.

The patient can swallow pasty food, reported lack of appetite, xerostomia - frequent flushes of OC were recommended. The patient was educated on food intake in smaller portions, more often + sipping. Psychological alteration occured with aggravation of symptoms the patient considered termination of treatment. Therapeutic communication was carried out.

Table 2. WHO Oral Mucositis Scale - case study 2

\begin{tabular}{|lccccc|}
\hline Day & \multicolumn{5}{c|}{ Degree of difficulty } \\
\cline { 2 - 6 } & $\begin{array}{c}\text { None } \\
\text { Soreness, } \\
\text { erythema, no } \\
\text { ulceration }\end{array}$ & $\begin{array}{c}\text { Erythema } \\
\text { ulceration, } \\
\text { patient can } \\
\text { swallow solid } \\
\text { diet }\end{array}$ & $\begin{array}{c}\text { Erythema } \\
\text { ulceration, } \\
\text { patient cannot } \\
\text { swallow solid } \\
\text { diet }\end{array}$ & $\begin{array}{c}\text { Mucositis to } \\
\text { the extent that } \\
\text { alimentation is } \\
\text { not possible }\end{array}$ \\
1 & No trouble & - & - & - & - \\
2 & - & - & Yes & - & - \\
$4-8$ & - & - & Yes & - & - \\
9 & - & - & - & Yes & - \\
14 & - & - & - & - & - \\
Last day of & - & Yes & & & -
\end{tabular}


25.9.2018 - apart from previous complications there was the addition of trismus, post-actinic reaction - third degree on the skin and mucous membranes of OC.

2.10.2018 - concomitant CHT wasfinished, RT was continued. The patient was advised to take effervescent aspirin, locally, half an hour before meals, to let it dissolve in the mouth. The patient reported elimination of pain; the diet was in liquid form. Oral mucosa was still swollen, painful, with localised ulcerations. Swelling in the neck area was smaller. Locally - on undamaged skin areas - Radiocare, on areas with damaged integrity - Framykoin + calcium panthotenicum.

The patient was educated on prohibition to shave the irradiated area, to wash it using baby soap, and to gently dry by touching with a cotton towel. Mood and mental state were improved, VAS 4.

\section{Discussion and conclusions}

The article focuses on oral complications accompanying oncostatic treatment. Changes of oral cavity mucous membranes occur in almost all patients undergoing radiotherapy treatment for head and neck tumours. According to several clinical studies, they are evident as early as during the first week of the treatment [6-9]. Apart from defects on mucosa, the treatment is also accompanied by significant pain [5], dysphagia, trismus, xerostomia $[10,11]$, distortion of the sense of taste, weight loss, and lymphoedema $[3,4,8]$.

During chemotherapy, changes occur, particularly in relation to its intensity and type or as a consequence of neutropaenia [12]. Defects of mucosa are evident in the course of several weeks from the start of the treatment $[3,9,10]$. The role of medical workers is regular monitoring of the patient. The nurse evaluates the changes in the oral cavity every day [11, 12], helps with oral hygiene, applies local treatment, and recommends an appropriate diet. The oncologist monitors the patient at least once a week and prescribes general and local treatment. During treatment at the oncology clinic the interdisciplinary team educates the patient on possibilities of self-care [13]. The objective of the qualitative study was to present specifics of nursing and collective oral care for patients after oncostatic treatment. In both case studies the nurse performed regular assessments of OC condition using the assessment tools specified. The oral care was basic and specific if pathological changes were identified. The activity included education (introductory, basic, complex, but also re-education), therapeutic communication, care for accompanying symptoms, and satisfaction of needs. Satisfaction of needs focused a lot on psychosocial needs, because mental deprivation occurred with both patients. The quality of the care was also evident at the moment of discharge of the patients; they were both stabilised and their symptoms were subsiding. According to the British Society for Disability and Oral Health [9] nursing interventions are aimed to control the oral cavity and oral hygiene, pain monitoring, total and local drug application, and education. Similarly, the studies $[6,11,13]$ claim that knowledge among nurses about complications in anti-cancer treatment, use of standardised assessment instruments, and care focused on the individual are essential for effective treatment.

Another objective was to point out the importance of interdisciplinary care in the treatment of oncology patients. Ambulatory or hospital treatment of oncological diseases requires cooperation of several professionals, but also of the patients themselves and of their families. An oncologist, a nurse, a nutrition assistant/nutritionist, a stomatologist, a dental hygienist, physiotherapist, speech therapist, a psychologist, a psychiatrist, and a cleric are essential [2, 14, 15]. The study [16] states that "...oral and dental care is affected by the patient's initial oral and dental condition, as well as the specific location of the cancer, the type, and its treatment; therefore, appropriate communication between the dentist and the oncology team is needed". Our clinical site consisted primarily of the oncologist, the nurse, the stomatologist, and the patients. Both patients had repaired teeth before starting oncological therapy. Mutual cooperation was efficient despite the problems in the middle of the treatment of the second patient, which were removed after mutual communication and recovery of trust.

The last objective was to compare oral care of chemotherapy and radiotherapy patients. Oral care during chemotherapy is focused on infection prevention in neutropaenia of the patients, and importance is placed on education about regular hygiene, regular monitoring of oral mucosa, and supporting treatment. If infection occurs, the patient is prescribed antibiotic treatment, special oral care (three times a day), regular hygiene, and flushes of OC if oral intake of food and liquids is continued. It is also important to control the oral source of viral, bacterial, or fungal infection in patients with fever of unknown origin $[17,18]$. In the case of radiotherapy, complications are expected, and they occur earlier. The treatment depends on the degree of mucositis and associated symptoms; for example, monitoring the patient for trismus, and checking for pain or weakness in masticating muscles in the radiation field $[19,20]$.

The situation was similar in our patients. The patient undergoing radiotherapy experienced changes of mucosa earlier, they were accompanied with other complications: xerostomia, pain, lack of appetite, later trismus and postactinic reaction - third degree on the skin and mucous membranes of OC. The treatment was local (local treatment of mucous membrane and also of the irradiated skin) and general. In the case of the patient treated with chemotherapy, symptoms oc- 
curred on the sixth day, the complication being neutraopenia, which endangered the overall condition of the patient and was the reason for the initiation of fully enteral nutrition.

\section{Conflict of interest}

The authors declare no conflict of interest.

\section{References}

1. Hudáková Z, Fialová A, Kokorud’ová J. Onkologické ošetrovatel'stvo. Verbum, Ružomberok 2012.

2. Vorlíček J, Abrahámová J, Vorlíčková H. Klinická onkologie pro sestry. Grada, Praha, 2012.

3. Vokurka S. Mukozitída dutiny ústní po chemoterapii a aktinoterapii v bežné praxi. Interní Medicína 2009; 2: 77-79.

4. Hudáková, Z, Novysedláková, M. Onkologické ošetrovatel'stvo 2. Verbum, Ružomberok 2012.

5. O'Connor P, Bissn J, Asplin P, Gahir D. Retrospective analysis of self-reporting pain scores and pain management during head and neck IMRT radiotherapy: a single institution experience. Radiography 2017; 23: 103-106.

6. Rosenberg V. Orálna mukozitída pri rádioterapii nádorov hlavy a krku a možnosti jej terapeutického ovplyvnenia. Onkológia 2014; 9: 308-310.

7. Franco PL, Martini S, Di Muzio J, Cavallin C, Arcadipane F, Rampino M, Ostellino O, Pecorari G, Garzino Demo P, Fasolis M, Airoldi M, Ricardi U. Prospective assessment of oral mucositis and its impact on quality of life and patient-reported outcomes during radiotherapy for head and neck cancer. Med Onkol 2017; 34: 9-13.

8. Hajdu SF. Swallowing therapy and progressive resistance training in head and neck cancer patients undergoing radiotherapy treatment: randomized control trial protocol and preliminary data. Acta Oncol 2017; 56: 354-359.

9. Lalla R, Sonis S, Peterson D. Management of oral mucositis in patients with cancer. Dent Clin North Am 2008; 52: 61-viii.

10. Gautam AP, Fernandes DJ, Vidyasagar MS, Maiya AG, Nigudgi S. Effect of low-level laser therapy on patient reported measures of oral mucositis and quality of life in head and neck cancer patients receiving chemoradiotherapy a randomized controlled trial. Support Care Cancer 2013; 21: 1421-1428.

11. Araujo NM, Luz MH, da Silva GR, Andrade EM, Nunes LC, Moura RO. Cancer patients with oral mucositis: challenges for nursing care. Revista Latino-Americana de Enfermagem 2015; 23: 267-274.

12. Murphy BA. Mucositis-related morbidity and resource utilization in head and neck cancer patients receiving radiation therapy with or without chemotherapy. J Pain Symptom Manag 2009; 38: 522- 532.

13. Bučková S, Karabová Z. Úroveň vedomostí sestier o febrilnej neutropénii v onkologickom ošetrovatel'stve. Diagnóza v ošetřovatelství 2013; 9: 5-7.

14. British Society for Disability and Oral Health. The Oral Management of Oncology Patients Requiring Radiotherapy, Chemotherapy and/or Bone Marrow Transplantation. 2018; 85.

15. Knoos M, Ostman M. Oral Assessment Guide - test of reliability and validity for patients receiving radiotherapy to the head and neck region. Eur J Cancer Care 2010; 19: 53-60.

16. Bužgová R, Sikorová L, Kozáková R, Jarošová D. Hodnotící nástroje pro zjistoování potřeb pacientu v paliativní péči. Onkologie 2013; 7: 310-314.

17. Jurga M. Klinická a radiačná onkológia založená na dôkazoch. Osveta, Martin 2010.

18. National Institute of Dental and Craniofacial Research. Prevention and management of oral complications head and neck radiation therapy. 2009. 10 p. www.nidcr.nih. gov

19. Wonk MH. Oral Complications and Management Strategies for Patients Undergoing Cancer Therapy. Sci World J 2014; 2014: 581795.

20. Elad S. The MASCC/ISOO Mucositis Guedelines 2019 Update: introduction to the first set of article. Supportive Care in Cancer 2019, 27: 3929-3931.

\section{Address for correspondence:}

\section{PhDr., PhD. Katarína Zrubákova}

Department of Nursing

Faculty of Health

Catholic University

Ruzomberok, Slovak Republic

Phone: +421918722187

E-mail: katarina.zrubakova@ku.sk 